\title{
EVALUATION OF TOURISM MARKETING COMMUNICATIONS PUNCAK SOSOK AS DESTINATION OF NIGHT TOURISM IN BANTUL
}

\author{
Estavita Chantik Pembayun $^{1}$, Yenni Sri Utami ${ }^{2}$, and Isbandi Sutrisno ${ }^{3}$ \\ ${ }^{1 \& 2}$ Department of Public Relations \\ ${ }^{3}$ Department of Communication Science \\ Faculty of Social and Political Sciences, UPN "Veteran" Yogyakarta \\ estavitapembayun@gmail.com
}

\begin{abstract}
As a night tourist destination that is unique and has great potential, Puncak Sosok requires an evaluation of Puncak Sosok's marketing communications. The formulation of the problem in this research is how to evaluate marketing communication conducted by Puncak Sosok managers. The purpose of this research is to describe and to find out the evaluation of Puncak Sosok marketing communication and the supporting and inhibiting factors in its implementation. This research uses eight main marketing communication models by Kotler and the PII (Preparation, Implementation, Impact) evaluation model by Cutlip-Center-Broom with a qualitative approach. The results of the evaluation on the preparation aspect are conformity with the objectives and background where fluctuations in visits, but there are no details number of the tourist targets so that the measurement of success is not detailed. Evaluation on the implementation aspect are that most of the programs have been running well, but there are problems such as social media creativity and the absence of tour packages and authentic Puncak Sosok products. Impact evaluation results on most programs have had a positive impact such as the number of media publications and known as a typical night tourism destination with live music. Nevertheless, some programs are still ineffective and need to be improved, such as direct marketing and personal selling programs, which have less impact on attracting tourists. Supporting factors are the relationship that exists with the media and stakeholders, while the lack of innovation and knowledge of human resources in marketing and media use become inhibiting factors.
\end{abstract}

Keyword: PII Evaluation, Tourism Marketing Communication, Puncak Sosok

\section{INTRODUCTION}

Bantul has great potential as a tourism area. The increasing number of visitors is one of the driving factors for increasing the income of local residents. This is evidenced by the data of Local Revenue from the tourism sector, Bantul
Regency which continues to experience an increase. In 2012, PAD was recorded to receive $\mathrm{Rp} 5$ billion, then increased to 11 billion in 2015 and increased again to $\mathrm{Rp}$ 29 billion in 2018. In 2016, the number of visitors reached 5,148,633, then in 2017 it increased by $77.54 \%$ means an increase of 
$3,992,517$ visitors. In 2018, the number of tourists increased by $3.28 \%$, namely 300,708 visitors (visitingjogja.com, 2019).

Tabel 1. Number of Tourists in Bantul Regency

\begin{tabular}{|c|c|}
\hline Year & Number of Tourists \\
\hline 2016 & 5.148 .633 \\
\hline 2017 & 9.141 .150 \\
\hline 2018 & 9.441 .858 \\
\hline
\end{tabular}

Based on the Law of the Republic of Indonesia No. 10 of 2009 Regarding tourism, the tourism destination, hereinafter referred to as a tourism destination, is a geographical area within one or more administrative regions in which there are tourist attractions, public facilities, tourism facilities, accessibility, and communities which are interrelated and complement the realization of tourism.

Puncak Sosok was established in December 2017 and officially became a tourist destination in March 2018. It is located in Jambon, Bawuran Village, Pleret, Bantul Regency. As a night destination, Puncak Sosok can be enjoyed every day starting at 15:00 - 00:00 WIB with the entrance fee as sincere. In addition to via Instagram, promotional tools that are used include social media facebook, media publicity, events, and websites with subordinate domains.Bantulkab.go.id. As a tourist destination that implements the principle of Community Based Tourism, Puncak Sosok always involves the active participation of the people of Bawuran Village starting from the initial stage until now, Puncak Sosok has been established, the community is always actively involved to jointly prosper the community through tourism.

Competition in the field of tourism is getting tougher, but the majority of Punsok managers are middle-to-lower class people who are still unfamiliar with tourism and have only capital. The manager has difficulty innovating because he does not have a reference data to develop. Until now there have been many Bantul tourist destinations that are rarely visitors even closed in a span of less than 5 years. That is because people who handle it die or move without regeneration or the absence of new innovations. As happened in the vineyards in the Bambanglipuro and Kali Buntung Tourism Village in the Jetis area, Bantul (Hendrayanti, 2019).

The results of the prasurvey interview with the manager of Puncak Sosok and Bantul Tourism Officer revealed the problems and threats that occurred related to the marketing communication of Puncak Sosok, as an outstanding tourist destination by achieving third place in the 
category of national youth pioneering youth in the field of natural resource management and tourism on 2019, potential and unique. The marketing communication strategy that has been implemented must be evaluated in order to be able to further develop of Puncak Sosok and the achievement of the destination as a tourist destination that is prosperous for the peoples.

\section{PII Theory (Preparation, Implementation and Impact)}

According to Cutlip-Center-Broom in the book Effective Public Relations cited by Morissan, M.A (2008: 226) describes the evaluation divided into 3 stages, Preparation, Implementation and Impact. These stages include an evaluation of the outcome and income. PII evaluation does not provide a specific methodology, but assumes that all programs and campaigns will be measured by social science methodologies that will be supported / funded by clients / business owners (Wasesa and Macnamara, 2013: 283). Noble \& Watson explained the evaluation stages as follows:

Preparation Phase, Tests whether sufficient background and information have been collected in order to plan an effective program. In addition to gathering information that will be the foundation of the program. The next thing that needs to be tested is the content and message of the material produced. The purpose of this test is to ensure that the content and message is in accordance with the pre-planned plans that have been made.

Implementation Phase, Conducting research on how the strategies and tactics of the program are implemented. Evaluation can start from the distribution of program materials and the amount of attendance at a special event, to how to bring the target public to understand the core messages carried by the organization. Evaluation at this stage can identify deficiencies in a program, for example such as the distribution error of media broadcasts or errors in the use of communication media.

Researcher collected information about the implementation of Puncak Sosok marketing communication program and reviewed the implementation with the concepts used in the research, namely using the elements of the marketing communication mix according to Kotler and Keller which consisted of eight main communication models, namely advertising, sales promotion, Events and Experiences, Public Relations and Publicity, Direct Marketing, Interactive Marketing, Word of Mouth Marketing, and Personal Selling. 
The form of implementing the elements of Kotler's marketing communication mix can be seen in the Puncak Sosok marketing communication strategy. In the advertising aspect, Puncak Sosok does not do offline advertising, but uses advertisements on websites and social media. Puncak sosok does not rent certain spaces such as using advertisements in electronic media, television, radio, or print media. Apart from going through the Bawuran Village website and social media, Puncak Sosok also uses posters needed in a special event. The use of promotional strategies with advertising on social media and posters is the mainstay strategy of Puncak Sosok because it is practical, effective and low cost to inform tourists.

The aspect of sales promotion in tourism is generally in the form of tour packages and rental discounts, but this has not been implemented by Puncak Sosok. The unavailability of tour packages is due to the very limited availability of Puncak Sosok facilities. Even so, the manager said that some visitors to Puncak Sosok expected a tour package provided by Puncak Sosok. Until now, visitors who want to enjoy the facilities at Puncak Sosok in groups or more than a day can still get low prices with the negotiation system or by request. From the cases that occur, the
Tour Package is an important thing for tourism promotion. The existence of a Tour Package aims to make it easier for tourists in the process of buying and selling products or renting the facilities provided with prices that are stated in detail and clearly. As explained by Kotler and Keller (2012: 541) "Sales promotion, a key ingredient in marketing campaigns, consist of a collection of incentive tools, mostly short term, designed to stimulate quicker or greater purchase of particular products or services by consumers or the trade". Advertising offers a reason to buy, whereas sales promotions offer an incentive to buy. This strategy is quite effective in establishing good relations with travel agents by establishing good relationships with various local and national travel agents with Puncak Sosok.

In the aspect of events and experiences, Puncak Sosok carried out by organizing music and cultural-based activities or events that can reach many potential tourists who do not like advertisements. The event which was carried out through live music was enlivened by selected bands so that the performers of this event were not just any band. The manager will ask for a video appearance from the potential filler to see the quality. Bands that pass the selection by 
the management will be contacted and then appear on the Puncak Sosok stage directly. The culture-based event that has been held is the Bawuran Fest. BawuranFest covers a wide range of events and offers the experience of enjoying the culture at Puncak Sosok firsthand. Live music event activities are also an option for the Puncak Sosok marketing strategy which is routinely carried out almost every day. This program is effective in marketing to prospective tourists so that they are interested in visiting and enjoying the experience of the music directly while enjoying the view of the city of Yogyakarta from the top. This is because there is no night tourism destination in Bantul and even Yogyakarta that offers a similar concept, so that it becomes its own characteristic and uniqueness. This has been confirmed by the Management of Puncak Sosok and the Tourism Office. Even the concept of live music with a view on Puncak Sosok has been used as a role model by other tourist destinations to later hold the same concept.

The impact of this activity also affects aspects of Public Relations and Publicity. Puncak Sosok participated in delivering marketing messages through publicity coverage from the media. Puncak People use messages that they feel are more trustworthy than advertising. As stated by
Rodrigues (Lohmann, 2017: 121) that in tourism marketing, it is important to deliver value to consumers because tourism products are something that is not physical, therefore the value received by consumers greatly determines tourist decisions.

Publicity from Puncak Sosok has strength in the media, one of which is through the unique concepts and events in Puncak Sosok such as natural beauty and live music exposed by the media. An image was built that Puncak Sosok was a distinctive and unique tourist destination. In addition to establishing good relations with the media, news is also carried out through social media, such Facebook, Instagram, and YouTube,and also supported by the Bawuran Village website www.bawuran.Bantulkab.go.id.

Word-of-Mouth Marketing also influences Puncak Sosok's marketing. Word of mouth is oral, written, and electronic communication between people related to the advantages or experiences of buying or using a product or service. Puncak Sosok serves tourists to be able to find it easy to travel to Puncak Sosok through partnerships with communities in Yogyakarta and several big cities in Indonesia. The attractiveness of Puncak Sosok is proven by the existence of the hashtag \#PuncakSosok as many as 5000+ 
posts on media social Instagram from March 22, 2020.

Word-of-Mouth Marketing also occurs via word of mouth and WhatsApp application. Marketing about Puncak Sosok carried out through groups of communities, which have hundreds or even thousands of members. This happens because of the satisfaction and good experiences felt by tourists so that they are willing to recommend Puncak Sosok to others. Puncak Sosok use one of several forms of interactive marketing as explained by Lohmann (2017: 125) Interactive Marketing is an online activity and program designed to engage customers or prospects and directly or indirectly increase awareness, improve image, or create product sales and services, which is social media Instagram. This Instagram account @Puncak_Sosok is interactive and meets the criteria described by Lohmann.

The Puncak Sosok Instagram account can be said to be interactive but less informative. According to the manager, there are still frequent tourists visiting during the day, while Puncak Sosok itself is a night tourist destination. In addition, related to the live music program, there is no information regarding the schedule of the performers so that visitors often come to enjoy live music, but on that day live music is being abolished. The ineffective use of Instagram accounts as informative media is due to the lack of initiative taken by the manager. Even though it's not very informative, the Instagram account @Puncak_Sosok is interactive enough, such as the availability of the Direct Message service and the comments column, as well as showing the state of Puncak Sosok directly or live when the live music program is held through the live story on Instagram feature. The manager also reshares posts from tourists that tag Puncak Sosok on their Instagram account as a form of interaction.

The results reveal that tourists feel the content listed on Puncak Sosok Instagram account is monotonous and less attractive. There is no identity of Puncak Sosok content to attract tourists. Approximately $90 \%$ of the content from Puncak Sosok Instagram account are reposts of visitor uploads. This factor is due to the lack of creativity on the part of social media managers.

The suitability of the promotion mix concept described by Kotler and Keller (2012: 240) with the marketing communication strategy carried out by Puncak Sosok is then found in the direct marketing and personal selling aspects. Puncak Sosok is involved by the Bantul 
Regency Tourism Ministry in the activities of travel dialogue, fam-trips (familiarization trips) and travel fairs. In addition to the travel dialogue program, fam-trips (familiarization trips) and travel fairs, this aspect is also carried out independently by Puncak Sosok.

Direct marketing carried out by Puncak Sosok by following the travel dialogue activities and family trips (familiarization trip) that bring together the management of Puncak Sosok directly with tourists. In addition, Puncak Sosok also uses telephone and WhatsApp Application.

In accordance with Kotler and Keller's explanation that direct marketing is the use of direct tourist channels to reach and deliver goods and services to customers without using marketing intermediaries. By doing direct marketing, Puncak Sosok and tourists can communicate directly, and get data or short analysis of what tourists are asking and directly what tourists want. So that it can be used as an evaluation material for Puncak Sosok. The direct marketing carried out independently by Puncak Sosok is related to Sosok Coffee products. Archipelago coffee that is labeled Sosok Coffee, to attract coffee lovers in Yogyakarta to visit Puncak Sosok. It's done by directly inviting coffee lovers through Ngopi Senja event held by Puncak Sosok on May 26, 2019, to taste and buy Sosok Coffee products. It's just that direct marketing activities are constrained by human resources who manage Puncak Sosok who are quite minimal in terms of tourism knowledge, so that it cannot be done optimally and tends to be done by only a few people in the management structure.

The next Puncak Sosok promotion is personal selling. From the results of the research, Puncak Sosok carried out this strategy by taking advantage of the opportunity to participate in the travel fair event in the tourism exhibition stand held by the Tourism Ministry with the aim of attracting new tourists. Through this program, the manager of Puncak Sosok provides information to potential customers about what activities can be done while visiting Puncak Sosok. However, this strategy cannot be implemented optimally, because it only follows the program from the Tourism Ministry. Personal sales carried out independently by the manager are related to the existence of Sosok Coffee, but this is not selling well because the coffee products sold are Indonesian coffee which is only labeled Sosok Coffee.

From the implementation of Puncak Sosok Marketing Communication, it can be seen that the promotion mix of the 
marketing communication mix elements according to Kotler and Keller. Evaluation on the implementation aspect of Puncak Sosok marketing communication shows that the implementation of all programs has mostly been going well, but there are several problems such as the lack of knowledge of Puncak Sosok human resources in the tourism sector and initiatives in terms of creativity related to social media accounts are less than optimal and only interactive rather than informative and persuasive. Problems were also found related to the absence of tour packages and original Sosok Peak products.

The Impact Phase, the Evaluation switches to testing whether the program goals and objectives that have been set previously can be achieved as desired. This evaluation is based on the measurement of the same variable, which becomes a reference in the program to show whether the measured changes are able to answer the objectives to be achieved. The form or technique of measurement carried out can be in the form of surveys or observations. In this stage, can find out the number of public targets who understand the core message delivered, changes in opinion, to changes in attitude. In the Impact evaluation stage, the researcher collects information and data about the effects of the program. At this stage, it will also produce recommendations on how the program should be implemented, resumed or terminated.

\section{Tourism Marketing Communication}

Some elements that make up marketing communication are called the marketing communication mix or promotion mix. In Kotler and Keller (2009: 174) the elements of the marketing communication mix consist of eight main communication models are Advertising, Sales Promotion, Events and Experiences, Public Relations and Publicity, Direct Marketing, Interactive Marketing, Word of Mouth Marketing, and Personal Selling.

According to Kotler (2009: 74)

Advertising are all forms of nonpersonal presentations and promotions paid about, ideas, goods, services, or places by advertisers (government, companies, organizations) that are clearly identified. Advertising about a destination or travel package can be placed in various electronic and print media. Ads that want to maximize dramatization usually choose audio-visual like television.

Sales Promotion is one of the determining factors for the success of a marketing program. Sales promotion is all activities that aim to deliver or communicate a product or service to the 
target market to take immediate action. Kotler and Keller (2012: 541) say "Sales promotion, a key ingredient in marketing campaigns, consist of a collection of incentive tools, mostly short term, designed to stimulate quicker or greater purchase of certain products or services by consumers or the trade". Advertising offers a reason to buy, whereas a sales promotion offers an incentive to buy.

Events and Experiences are the organization of activities or programs sponsored by the company / destination to create continuous or special interaction with a brand. These activities are companysponsored activities and programs that are designed to create daily interactions or interactions related to specific brands, related to interactions with consumers, including arts, sports, entertainment and less formal activities.

The old name for Public Relations is publicity, the task of securing editorials as opposed to paid-space in print or broadcast media to promote or "praise" products, services, ideas, places, people or organizations.

Direct marketing is an interactive marketing system, by utilizing one or several advertising media to cause measurable responses and know a transaction. In this system, the communication made is directed directly to individual consumers, so that messages can be responded to by consumers concerned.

Lohmann, (2017: 125) interactive marketing is included in the tourism promotion mix. Interactive Marketing is an online activity and program designed to engage customers or prospects and directly or indirectly increase awareness, improve image, or create sales of products and services.

Word of Mouth Marketing is oral or written communication from people or electronic communication relating to the results or experience of visiting a destination area. The key aspects of social networking are word of mouth and the number and nature of conversations and communication between various parties. Word of mouth marketing is oral, written, and electronic communication between people that relates to excellence or experience buying or using a product or service.

Personal Selling is direct interaction with one or more prospective tourists to give presentations, answer questions, or generate sales.

\section{Methods}

This research uses a qualitative approach, which is an approach that is 
constructed as a research strategy that uses more emphasis on words rather than quantification in data collection and analysis. According to Sugiyono (2007: 1) qualitative research is a method used to examine the condition of natural objects, where researchers as key instruments, data collection techniques are carried out in a combined manner, data analysis is inductive and the results emphasize the meaning of generalization. The object of this research is Puncak Sosok's marketing communication as a night tourism destination by examining the supporting and inhibiting factors both internal and external from the marketing communication that has been done by Puncak Sosok.

This research tested the validity of the data by prioritizing the confirmation aspect through the triangulation of sources. Source triangulation was performed using data sources. After the researcher interviewed all the sources, then matched the data from the expert's opinion as a comparison. This is done to be able to prove the validity of the data. In this research, the authors chose sources from Puncak Sosok manager, the chairman and management, and visitors of Puncak Sosok and the Bantul Tourism Ministry to balance the information obtained from interviews with the internal management of Puncak Sosok.

\section{Discussion}

The marketing communication strategy used by Puncak Sosok is to realize the vision of Puncak Sosok for "the realization of quality, competitive and competitive Bawuran Village tourism for the welfare of the community". Based on the results of research conducted, at the planning stage of Puncak Sosok marketing communication strategy through 2 stages, namely the process of determining targets and determining promotional tools. The determination of the target of this marketing communication strategy is based on the vision, mission, and goals that have been set.

Puncak Sosok has general targets and specific targets. In general, the targets are communities in Yogyakarta and Indonesia and the general public without age and occupational restrictions. These promotional tools include through the internet media in the form of village websites and social media, and posters to inform events that will be held at Puncak Sosok, through exhibitions, organizing events, and through synchronizing marketing communication programs with the Bantul district tourism office. The 
program related to the marketing of Puncak Sosok was formulated with reference to the Bantul district regulation number 18 of 2015, concerning the regional tourism development master plan (RIPPARDA). In this RIPPARDA has arranged the development of tourism in the area in 20152025. The mission of regional tourism development is to develop tourism marketing that is integrated, responsible, and wide-scale to increase tourist visits by following technological developments.

The marketing communication program activities carried out by Puncak Sosok with the Bantul tourism agency include tourism development and assistance in marketing of Puncak Sosok through active involvement in various promotional activities for tourist destinations. Bantul tourism office has conventional and digital promotional activities. In conventional promotions there are activities both nationally and internationally, travel dialogue activities, familiarization trips, events and travel fairs.

Besides participating in the program from the Tourism Agency, Puncak Sosok also has a strategy that is managed independently. In marketing of Puncak Sosok, the manager uses promotion mix in marketing communication. Advertising via the Internet by utilizing internet technology is using social media namely websites, facebook, instagram and YouTube as well as posters besides being posted on the bulletin boards, also distributed via the Village website, Instagram and WhatsApp social media. To attract tourists, Puncak Sosok holds a live music event almost every day. Puncak Sosok also holds a program to watch football matches or films to attract visitors from the community concerned. The people of Puncak Sosok also still preserve traditional cultural arts such as jatilan, kethoprak, shadow puppets, hadroh, mocopat, dance and angklung performances which are packaged in the cultural title event Bawuran Fest. Establishing a good relationship carried out by the PR division with the Department of Tourism and the media or the press is also one way to promote Puncak Sosok. These media both television media, newspapers and online media around tourism. Media that has covered Puncak Sosok include travel.kompas.com, detik.com, Suara.com, jogja.tribunnews.com, Kedaulatan Rakyat Newspapers, Jogja Daily, Aditv, Trans7, Sctv, Jogja TV at the Serba Serbi Jogja event, and other media. Direct marketing carried out by Puncak Sosok is related to Indonesian coffee products labeled Kopi Sosok, to attract coffee connoisseurs in Yogyakarta and surrounding areas. Puncak 
Sosok uses Instagram social media to establish interactive communication with tourists. For example, using the live Instagram Story feature to share the atmosphere of Puncak Sosok directly, also use the Direct Message feature to send messages to the admin if you have questions about Puncak Sosok. Besides that, Puncak Sosok manager also reshares photo posts from tourists on Instagram account as a form of interaction. Marketing through word of mouth or commonly referred to as word of mouth. This program was intentionally carried out by the managers of Puncak Sosok through communities in Yogyakarta. This program aims to make Puncak Sosok known to the public at large, especially those in Yogyakarta. One way to promote Puncak Sosok is to take advantage of opportunities when participating in events in the tourism exhibition stand with the aim to attract new tourists. In addition, sales with direct interaction with one or more potential tourists are also done when promoting Kopi Sosok.

The results of the preparation evaluation on the Puncak Sosok marketing communication strategy is that there has been a match between the background of the program and the strategy carried out by Puncak Sosok with a note of deficiencies namely in the breakdown of the number of tourist targets to be achieved by Puncak Sosok.

Evaluation on the implementation aspect of Puncak Sosok marketing communication shows that advertising is done on a small scale and uses owned media but the implementation is successful and carried out according to plan, the use of Instagram is effective enough to bring tourists, but not yet consistent in content management. The events that were held successfully carried out according to plan and became a tourist attraction and its own unique characteristics, but it has not been consistent in providing information about the filler schedule. Establish good relations with local and national media for message distribution, so that the image of Puncak Sosok is built as a unique night tourism destination. Successful dissemination of information through word of mouth is due to satisfaction and good experience so that tourists are willing to recommend Puncak Sosok.

From the evaluation results of Puncak Sosok Marketing Communication Impact it can be seen that there have been many publications by local and national media. Instagram social media has brought many new tourists, in the implementation of direct marketing and personal selling is 
less effective because there are no typical products of Puncak Sosok yet. Puncak Sosok is known as a unique nightlife destination with unique live music and concepts.

The supporting factors of Puncak Sosok marketing communication are an open attitude and understanding of the benefits of community tourism as well as a unique concept that has gained a good image among other tourist destinations. Closeness and good relations with the media and stakeholders (tourists) provide many opportunities to promote Puncak Sosok for free both through media punitively and word of mouth. The inhibiting factor of the marketing of Puncak Sosok is that the management has limitations in the knowledge of the tourism sector, as well as the unavailability of tour packages and authentic original products to be traded.

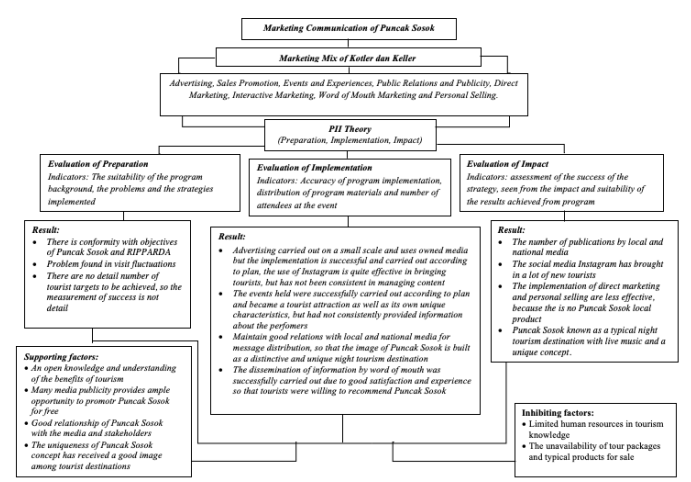

\section{Conclusion}

The marketing communication program implemented by Puncak Sosok independently includes advertising, events and experiences, public relations and publicity, interactive marketing and word of mouth marketing. Puncak Sosok participates in programs from the Bantul Tourism Office through the Bantul Explore, Direct Marketing and Personal Sales applications. Puncak Sosok carry out sales promotions in the form of tour packages.

$$
\text { Puncak Sosok marketing }
$$
communication program evaluation results as a reference in improving the program. The results of the evaluation in the preparation are the compatibility between the background of the program and the strategy that Puncak Sosok has done with the lack of detail in the number of tourists targets that Puncak Sosok wants to achieve. The evaluation results on the implementation show that advertising is carried out on a small scale and uses owned media but the implementation is successful. The events that were held successfully carried out according to plan and became a tourist destination and its own unique characteristics, but it has not been consistent in providing information about the filler schedule. Establish good relations with local and national media for message distribution, so that the image of Puncak 
Sosok as a unique night tourism destination is built. The results of the evaluation on the Impact aspect are a large number of publications by local and national media and are known as distinctive night tourism destinations with live music and unique concepts that increase the number of visitors. However, there are some programs that are still ineffective and need to be improved again such as programs in the aspects of direct marketing and personal selling which have less impact on attracting tourists.

The supporting factors of Puncak Sosok marketing communication are an open attitude and understanding of the benefits of community tourism as well as a unique concept that has gained a good image among other tourist destinations. The closeness and good relations that exist with the media and stakeholders (tourists) provide many opportunities to promote Puncak Sosok for free both through media punitively and word of mouth. The inhibiting factor of Puncak Sosok's marketing communication is that the manager has limited knowledge in tourism, as well as the unavailability of tour packages and authentic original products for sale.
Arikunto, S dan Jabar, CSA. (2004). Evaluasi Program Pendidikan : Pedoman Praktis Bagi Praktisi Pendidikan. Jakarta:PT Bumi Aksara.

Bungin, B. (2015). Komunikasi Pariwisata Pemasaran dan Brand Destinasi, Jakarta:Prenadamedia group.

Freddy, R. (1997). Analisis SWOT Tehnik Membedah Kasus Bisnis. Jakarta: PT Gramedia Pustaka Utama.

Haryono, W. (2003). Azas-azas Pembinaan Daerah Rekreasi dan Pariwisata. Bandung: Aktripa Yapari.

Kotler, P and Keller, KL. (2009). Manajemen Pemasaran, Edisi Ketiga Belas (Alih Bahas dari Bahasa Inggris oleh Sabran B) Edisi 13. Jilid 2. Jakarta:Erlangga.

Kolter, P dan Keller, K. (2012). Marketing Management 13th Edition. New Jersey: Pearson Education.

Lohmann, G dan Netto, AP. (2017). Tourism theory: Concepts, Models and Systems. Oxforshire: CABI (www.cabi.org).

Mill, RC. (2000). Tourism: The International Business; Penerjemah, Tri Budi Satrio. Jakarta: PT Raja Grafindo Persada.

\section{References}


Morrison, A.M. (2013). Marketing and Managing Tourism Destination. London:Routledge.

Sudjana, D. (2008). Evaluasi Program Pendidikan Luar Sekolah. Bandung:PT Remaja Rosdakarya.

Sugiyono. (2007). Metode Penelitian Kuantitatif, Kualitatif, dan R\&D. Bandung:Alfabeta.

Wasesa, SA., dan Macnamara, J. (2013). Strategi Public Relationss. Jakarta:Gramedia Pustaka Umum.

Watson,T and Noble, P. (2007). Evaluating Public Relationss: A Best PracticeGuide to Public Relationss, Planning, Research, and Evaluation. Second Edition. United Kingdom: Kogan Page Journal.

Adhanisa, C dan Fatchiya, A (2017). Efektivitas Website dan Instagram sebagai Sarana Promosi Kawasan Wisata Berbasis Masyarakat. Jurnal Sains Komunikasi dan Pengembangan Masyarakat [JSKPM], Vol. 1 (4): 451-466.

Boronyak, AC \&Paddon, M. (2010). Effective Community Based Tourism: a best practice manual for Peru. Sustainable Tourism, 1-2
Online

http://ejournal.skpm.ipb.ac.id/inde x.php/jskpm/article/view/119

Dewi K,A. (2019) Evaluasi Strategi Komunikasi Pemasaran Desa Wisata Sebagai Community Based Tourism (Studi Kualitatif pada Desa Wisata Krebet, Sendangsari, Pajangan, Bantul). Diss. Universitas Pembangunan Nasional Veteran Yogyakarta.

Fairuza, M. (2017) .Pembangunan inklusif pada sektor pariwisata (studi kasus wisata Pulau Merah di kabupaten Banyuwangi). Jurnal Kebijakan dan Manajemen Publik, 5(3), pp.1-13 2017.

Purbasari, N dan Asnawi. (2014). Keberhasilan Community Based Tourism Di Desa Wisata Kembangarum, Pentingsari dan Nglanggeran. Jurnal Teknik PWK Volume 3 Nomor 32014.

Online http://ejournals1.undip.ac.id/index. php/pwk

Rachmawati, E., Muntasib, H. \& Sunkar, A. (2011). Interaksi sosial masyarakat dalam pengembangan wisata alam di kawasan Gunung Salak Endah. Jurnal Forum 
Pascasarjana, 34(1), pp.23-32 2011.

Sugiyama, K dan Andree, T. (2011).

The Dentsu Way: Secrets of

Cross Switch Marketing from the

World's Most Innovative

Advertising Agency. New York,

United States: McGraw Hill

Professional.

Tolkach, D dan King, B. 2015.

Strengthening Community-Based

Tourism in a new resource-based

island nation: Why and how.

Elsevier Tourism Management

Journal,www.elsevier.com/locate/to

urman.

Internet

https://anugerahpesonaindonesia.com/whats

-on/api-2017 accessed 20 November 2019

www.perform.or.id/files/modulprosbumd04

Find.pdf, h.3 accessed 1 Desember 2019

https://visitingjogja.com/?s=data+statistik

accessed 24 Oktober 2019

https://www.voaindonesia.com/a/indonesia-

harus-memaksimalkan-pengembangan-

desa-wisata-135821073/102280.html

accessed 25 Oktober 2019 